\title{
Changes in Lipid Profiles after Switching to a Protease INHIBITOR-CONTAINING CART - UNFAVOURABLE EFFECT OF Fosamprenavir in OBese Patients
}

\author{
M. Gyalrong-Steur, J. R. Bogner, U. Seybold \\ Infektionsabteilung der Medizinischen Poliklinik, Campus Innenstadt, Ludwig-Maximilians-Universität, München, Germany
}

\begin{abstract}
Objective: One focus in the medical care of HIV-infected patients today is cardiovascular risk reduction. Metabolic disturbances occur frequently in patients taking protease inhibitors (PI) and are a major risk factor for atherosclerosis. With few published head-tohead studies substance-specific differences concerning metabolic effects are insufficiently defined. Therefore this cohort study directly compared the metabolic profiles of boosted atazanavir $(\mathrm{ATV} / \mathrm{r}$ ), fosamprenavir $(\mathrm{FPV} / \mathrm{r}$ ) and saquinavir (SQV/r).

Methods: Data from a cohort of 124 HIV patients initiating a boosted regimen with one of the PIs at the University of Munich (LMU) infectious diseases outpatient clinic were retrospectively analyzed. The main outcome measures were median absolute total cholesterol levels and median relative change of total cholesterol levels after six months of PI-therapy. A multivariate linear regression model was built to identify and control for potential confounders of the association between PI-therapy and serum cholesterol level. Results: 84 patients were treated with ATV/r, 23 patients received FPV/r and 17 patients SQV/r. Demographically the cohort constituted a representative sample of HIV-infected patients in Germany. There were no statistically significant differences between the comparison groups at baseline.

After six months of therapy median serum cholesterol in the ATV/r group dropped significantly from $204 \mathrm{mg} / \mathrm{dl}$ to $186 \mathrm{mg} / \mathrm{dl}$, while in the $\mathrm{FPV} / \mathrm{r}$ and $\mathrm{SQV} / \mathrm{r}$ groups a rise in serum cholesterol levels was observed from $179 \mathrm{mg} / \mathrm{dl}$ to $204 \mathrm{mg} / \mathrm{dl}$ and from 173 $\mathrm{mg} / \mathrm{dl}$ to $209 \mathrm{mg} / \mathrm{dl}$ respectively. The multivariate linear regression model identified a significant interaction between BMI at baseline and treatment with FPV/r: patients with higher BMI showed more prominent increases in serum cholesterol while taking FPV/r compared to patients with lower BMI.

Conclusion: This cohort study demonstrated the most favourable impact on serum cholesterol levels and thus cardiovascular risk for $\mathrm{ATV} / \mathrm{r}$ compared to $\mathrm{FPV} / \mathrm{r}$ and SQV/r under real-life conditions. Given the statistical interaction detected between FPV/r and BMI further studies assessing metabolic profiles of different antiretroviral drugs in specific patient populations are urgently needed.
\end{abstract}

Key words: HIV, cART, protease inhibitor, atazanavir, fosamprenavir, saquinavir, lipids, cholesterol, triglycerides, glucose, metabolism, body mass index, dyslipidemia, obesity, cardiovascular risk, multivariate linear regression, statistical interaction

$\begin{array}{ll}\text { Abbreviations: } \\ \text { ATV/r } & \text { boosted atazanavir } \\ \text { BMI } & \text { body mass index } \\ \text { cART } & \text { combination antiretroviral therapy } \\ \text { FPV } / \mathrm{r} & \text { boosted fosamprenavir } \\ \mathrm{LPV} / \mathrm{r} & \text { boosted lopinavir } \\ \mathrm{PI} & \text { protease inhibitor } \\ \mathrm{PLHA} & \text { people living with HIV/AIDS } \\ \mathrm{RTV} & \text { ritonavir } \\ \mathrm{SQV} / \mathrm{r} & \text { boosted saquinavir }\end{array}$

\section{INTRODUCTION AND OBJECTIVES}

Metabolic and cardiovascular health issues are becoming an increasing problem in Germany and other industrialized countries. Cardiovascular complications [1-8] now are among the leading causes of mortality in these countries [9-12].

Since the introduction of combination antiretroviral therapy (cART) mortality due to AIDS-defining illnesses has considerably decreased among people living with HIV/AIDS (PLHA), resulting in an increase of life expectancy to almost that of the general population $[13,14]$. Therefore non-HIV-related causes of death, among them cardiovascular diseases, are becoming more relevant among PLHA [14-17]. In addition, both HIV-infection itself [18-21] and various antiretroviral drugs are also associated with increased cardiovascular risk [22-24]. Elevated serum cholesterol has been shown to be a major cause for atherosclerosis in numerous studies $[3-5,8]$ and this association has also been confirmed in PLHA [25].

With a broad spectrum of antiretroviral drugs available, the focus of HIV therapy today lies on managing the patients' overall health situation, including metabolic and cardiovascular as well as quality of life issues [26]. Choosing antiretroviral drugs with a favourable metabolic profile is the primary specific intervention recommended to minimize the cardiovascular risk burden in HIV-patients even before identification of oth- 
er modifiable cardiovascular risk factors potentially requiring drug therapy [27].

Protease inhibitors (PIs) are an essential part of modern cART and recommended as part of first-line HIV-therapy in different guidelines [28-31]. However, unfavourable metabolic effects like elevation of serum lipids, impaired glucose tolerance, and increased risk of myocardial infarction have mainly been associated with this drug class [22, 24, 25, 32-37]. The metabolic effects, especially the impact on serum lipids, is a class effect of PIs, however there seem to be substancespecific differences [24]. Thus, knowledge of the different metabolic profiles of the various PIs offers the possibility to optimize cAR'T efficacy while keeping cardiovascular risk as low as possible. Several newer PIs show fewer metabolic side effects than have been observed for ritonavir-boosted lopinavir (LPV/r) or ritonavir (RTV) in therapeutic dosage [24, 32-35, 3841]. Especially atazanavir (ATV) so far has shown a relatively favourable lipid profile [42-45]. Saquinavir (SQV) as well has been observed to have few negative effects on the serum lipids [46-49]. Data about the metabolic properties of fosamprenavir (FPV) are conflicting [50-52].

Currently available data do not allow for a concluding assessment of the differences of the various PIs' effect on lipid and glucose metabolism and cardiovascular risk. Moreover, to date little is known about the various interactions of the PIs' metabolic effects with other patient characteristics such as body mass index (BMI), blood pressure, or smoking habits, which influence a patient's metabolic situation as well.

The aims of the present study were to directly compare the three PIs ATV, FPV and SQV, for which favourable metabolic profiles have been observed in different studies, with regard to their influence on metabolic parameters affecting cardiovascular risk as well as assessing possible interactions of the PIs with patient characteristics like BMI and blood pressure.

\section{METHOdS AND STATISTICS}

This study took place at the Ludwig-Maximilians-University of Munich infectious diseases outpatient clinic. The University of Munich ethics committee approved the study. All HIV-infected patients seen between January 1, 2000 and March 31, 2008 were screened for their eligibility. All adult patients initiating therapy with ATV $300 \mathrm{mg}$ qd, FPV $700 \mathrm{mg}$ bid, or SQV $1000 \mathrm{mg}$ bid within a RTV-boosted cART-regimen (ATV/r, $\mathrm{FPV} / \mathrm{r}$ or SQV/r) for whom a follow-up of at least six months was available were included into the analysis. Double-PI therapy and changes of the cART regimen as well as initiation or changes of a lipid-lowering medication during the first six months of PI-therapy were not allowed.

Patients were usually seen at the clinic every three months. At these visits serum levels of cholesterol, triglycerides, and glucose, CD4 cell count and viral load, as well as blood pressure, weight, and current medication were routinely documented. All demographic, HIV-related, and metabolic data were extracted from patient files and the outpatient clinic database.

Cardiovascular risk was calculated for each patient at baseline and after 6 months of PI therapy using the HeartScore-tool developed by the European Society of Cardiology in the version specific for Germany [2, 3 , 53]. The Score value is calculated on the basis of age, gender, smoking behaviour, systolic blood pressure and serum cholesterol level and describes the risk of a fatal cardiovascular event within the next 10 years. According to European Joint Task Force guidelines a patient is considered at high cardiovascular risk if the score is above $5 \%[3,54]$.

This study was carried out as a retrospectively analyzed cohort study, the main outcome measures were median absolute total cholesterol levels and median relative change of total cholesterol levels after 6 months of PI-therapy.

To identify potential confounding variables influencing the association between PI-therapy and serum cholesterol level a multivariate linear regression model was designed. The outcome variable was serum cholesterol level after 6 months of therapy with one of the PIs, main predictor variables were PI used and baseline cholesterol. Collinearity was ruled out by assessing variance inflation. Potential confounding covariates known from the literature were assessed, variables shown to be confounders were included in the final model. All parameters in the final model were tested for two-way interaction.

All statistical analyses were performed using SPSS $^{\text {TM }}$ software, version 15.0 (SPSS, Munich, Germany). For comparison of the cohorts Kruskal-Wallis$\mathrm{H}$-test and $\mathrm{Chi}^{2}$-test were used, as applicable. Intragroup analyses of the changes of parameters over time were performed using the Wilcoxon-test for metric variables and the $\mathrm{McNemar}$-test for categorical variables.

\section{RESULTS}

\section{Patients and Baseline Characteristics}

During the study period 444 patients starting a PIcontaining regimen were seen at the outpatient clinic, 124 patients met eligibility criteria for inclusion into the analysis. Of these, 84 patients $(68 \%)$ initiated therapy with ATV/r, 23 patients (19\%) initiated therapy with $\mathrm{FPV} / \mathrm{r}$, and 17 patients (14\%) with SQV/r. The remaining patients were excluded because they were treated with a different PI (199 patients), received a double-PI-regimen or an unusual dosage of the PI (87 patients), or insufficient follow-up was available (34 patients). Additional follow up documentation of 24 months after starting PI-therapy was available for 86 patients. The baseline demographic and clinical characteristics of the patients are shown in Table 1. There were no significant differences with regard to demographic characteristics, HIV disease characteristics, antiretroviral therapy, or cardiovascular risk factors between the 3 groups receiving different PI-based cART at baseline.

\section{Metabolic Profile and Cardiovascular Risk}

The changes of different metabolic parameters examined during the first 6 months after initiating therapy with one of the PIs are shown in Table 2. 
Table 1. Baseline demographic and clinical characteristics of patients starting a new PI-based cART regimen.

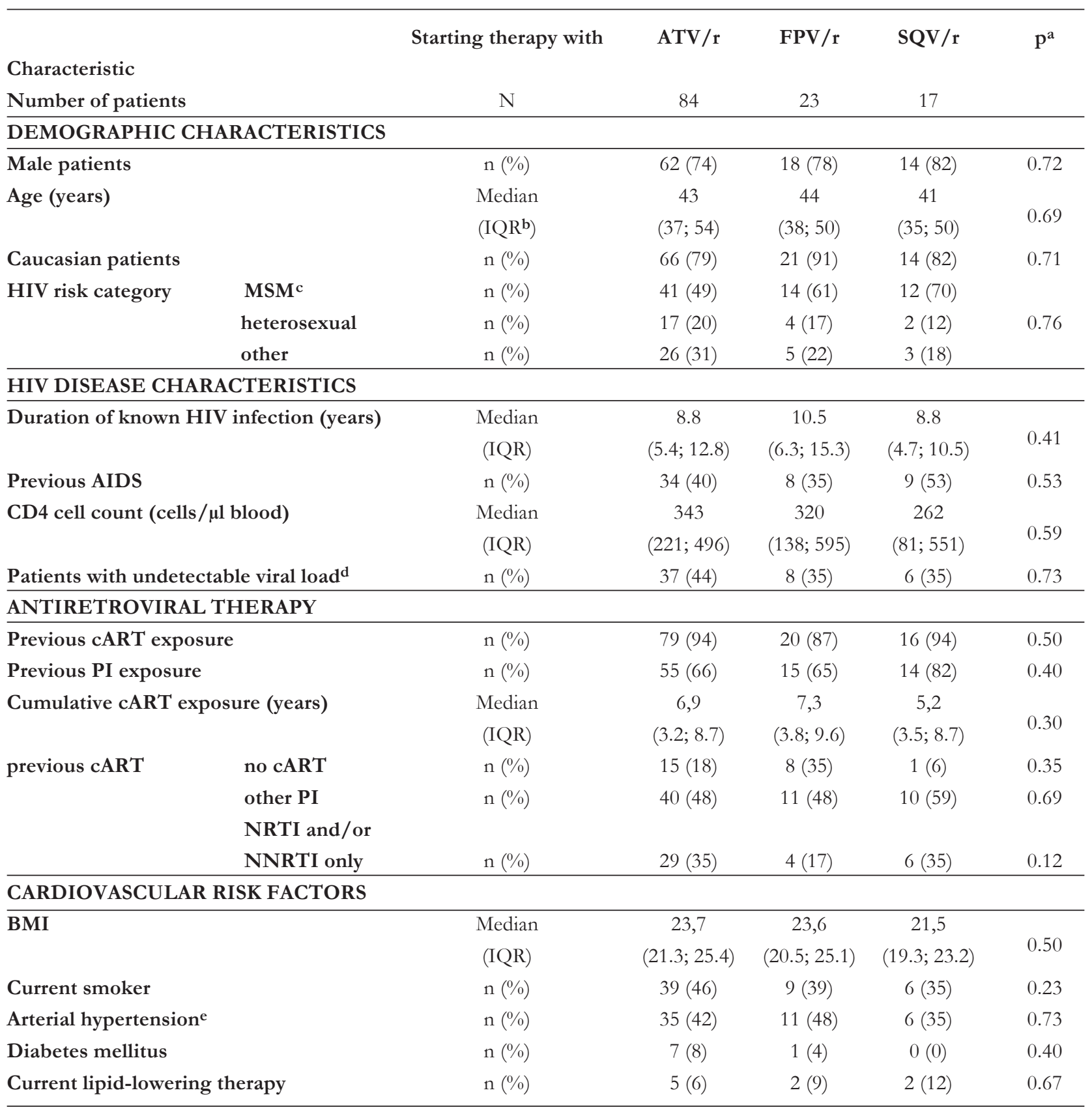

a: Kruskal-Wallis-H-test for metric variables, $\mathrm{Chi}^{2}$-test for categorical variables; $\mathrm{p}$-value for inter-group comparisons

b: inter quartile range

c: Men having sex with men

d: less than 50 copies per ml of plasma

e: diastolic blood pressure $\geq 90 \mathrm{mmHg}$ and/or systolic blood pressure $\geq 140 \mathrm{mmHg}$ or antihypertensive medication

At the time of starting PI-based therapy, the median serum cholesterol level was highest at $204 \mathrm{mg} / \mathrm{dl}$ in the ATV/r-group. In the FPV/r- and SQV/r-groups the median values were $179 \mathrm{mg} / \mathrm{dl}$ and $173 \mathrm{mg} / \mathrm{dl}$, respectively. The differences between the groups were not statistically significant $(\mathrm{p}=0.19$; inter-group comparison). After six months of therapy the median serum cholesterol level significantly decreased to 186 $\mathrm{mg} / \mathrm{dl}$ in the patients taking ATV $/ \mathrm{r}(\mathrm{p}=0.009$; intragroup comparison). The median value rose to 204 $\mathrm{mg} / \mathrm{dl}$ in the patients taking $\mathrm{FPV} / \mathrm{r}(\mathrm{p}=0.03$; intra- group comparison), and to $209 \mathrm{mg} / \mathrm{dl}$ in the patients taking $\mathrm{SQV} / \mathrm{r}(\mathrm{p}=0.15$; intra-group comparison). At month 6 of therapy there was a trend towards a lower median serum cholesterol in patients taking ATV/r $(p=0.055$; inter-group comparison) (Fig. 1). Regarding the relative change of the serum cholesterol levels at month 6 compared to baseline values, a significant difference between the PI groups was seen $(p=0.0002$; inter-group comparison): In the ATV/r-group serum cholesterol had decreased by $-6 \%$, in contrast to both the FPV/r- and SQV/r-group, in which a respective 
Table 2. Changes in the metabolic and cardiovascular profile during PI-therapy.

\begin{tabular}{|c|c|c|c|c|c|}
\hline \multirow{2}{*}{\multicolumn{2}{|c|}{$\begin{array}{l}\text { PI group } \\
\text { Characteristic }\end{array}$}} & $\mathrm{ATV} / \mathrm{r}$ & $\mathrm{FPV} / \mathrm{r}$ & $\mathrm{SQV} / \mathrm{r}$ & \multirow[t]{3}{*}{ p-value ${ }^{a}$} \\
\hline & & & & & \\
\hline \multicolumn{2}{|l|}{ Number of patients } & 84 & 23 & 17 & \\
\hline \multicolumn{6}{|l|}{ Serum cholesterol } \\
\hline at baseline $[\mathrm{mg} / \mathrm{dl}]$ & $\begin{array}{l}\text { Median } \\
\text { (IQR) }\end{array}$ & $\begin{array}{c}204 \\
(159 ; 251)\end{array}$ & $\begin{array}{c}179 \\
(148 ; 217)\end{array}$ & $\begin{array}{c}173 \\
(143 ; 221)\end{array}$ & 0.19 \\
\hline at month $6[\mathrm{mg} / \mathrm{dl}]$ & $\begin{array}{l}\text { Median } \\
\text { (IQR) }\end{array}$ & $\begin{array}{c}186 \\
(157 ; 228)\end{array}$ & $\begin{array}{c}204 \\
(177 ; 284)\end{array}$ & $\begin{array}{c}209 \\
(164 ; 278)\end{array}$ & 0.055 \\
\hline relative change at month 6 & $\%$ (Median) & -6 & +21 & +8 & 0.0002 \\
\hline \multicolumn{6}{|l|}{ Serum triglycerides } \\
\hline at baseline $[\mathrm{mg} / \mathrm{dl}]$ & $\begin{array}{l}\text { Median } \\
\text { (IQR) }\end{array}$ & $\begin{array}{c}187 \\
(113 ; 334)\end{array}$ & $\begin{array}{c}136 \\
(87 ; 289)\end{array}$ & $\begin{array}{c}205 \\
(143 ; 366)\end{array}$ & 0.20 \\
\hline at month $6[\mathrm{mg} / \mathrm{dl}]$ & $\begin{array}{l}\text { Median } \\
\text { (IQR) }\end{array}$ & $\begin{array}{c}186 \\
(119 ; 280)\end{array}$ & $\begin{array}{c}169 \\
(122 ; 239)\end{array}$ & $\begin{array}{c}218 \\
(120 ; 342)\end{array}$ & 0.90 \\
\hline \multicolumn{6}{|l|}{ Serum glucose } \\
\hline at baseline $[\mathrm{mg} / \mathrm{dl}]$ & $\begin{array}{l}\text { Median } \\
\text { (IQR) }\end{array}$ & $\begin{array}{c}90 \\
(82 ; 101)\end{array}$ & $\begin{array}{c}87 \\
(83 ; 97)\end{array}$ & $\begin{array}{c}89 \\
(78 ; 99)\end{array}$ & 0.70 \\
\hline at month $6[\mathrm{mg} / \mathrm{dl}]$ & $\begin{array}{l}\text { Median } \\
\text { (IQR) }\end{array}$ & $\begin{array}{c}91 \\
(83 ; 101)\end{array}$ & $\begin{array}{c}90 \\
(83 ; 103)\end{array}$ & $\begin{array}{c}97 \\
(89 ; 118)\end{array}$ & 0.17 \\
\hline \multicolumn{6}{|l|}{ High cardiovascular risk ${ }^{b}$} \\
\hline $\begin{array}{l}\text { at baseline } \\
\text { at month } 6\end{array}$ & $\begin{array}{l}\mathrm{n}(\%) \\
\mathrm{n}(\%)\end{array}$ & $\begin{array}{l}23(27) \\
20(24)\end{array}$ & $\begin{array}{c}2(9) \\
3(13)\end{array}$ & $\begin{array}{l}2(12) \\
3(18)\end{array}$ & $\begin{array}{c}0.088 \\
0.50\end{array}$ \\
\hline
\end{tabular}

a: Kruskal-Wallis-H-test for metric variables; p-value for inter-group comparisons

b: risk of developing a fatal cardiovascular event over the next ten years $>5 \%$, according to the HeartScore $[2,3,53]$

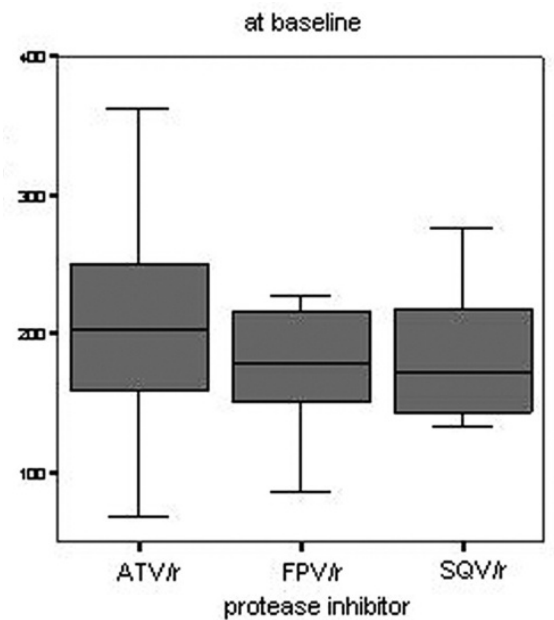

increase of $+21 \%(\mathrm{p}=0.0002$; comparison of $\mathrm{ATV} / \mathrm{r}$ and $\mathrm{FPV} / \mathrm{r})$ and $+6 \% \quad(\mathrm{p}=0.016$; comparison of $\mathrm{ATV} / \mathrm{r}$ and SQV/r) was observed. No significant difference could be found between the patients taking $\mathrm{FPV} / \mathrm{r}$ and those taking SQV/r $(\mathrm{p}=0.28$; comparison of $\mathrm{FPV} / \mathrm{r}$ and SQV/r) (Table 2).

In the further course between 6 and 24 months after initiating PI therapy cholesterol levels in patients on $\mathrm{ATV} / \mathrm{r}$ were continuously lower than in the other groups. In the ATV/r-group the median serum cholesterol at month 24 was $198 \mathrm{mg} / \mathrm{dl}$, in the $\mathrm{FPV} / \mathrm{r}$ - at month 6

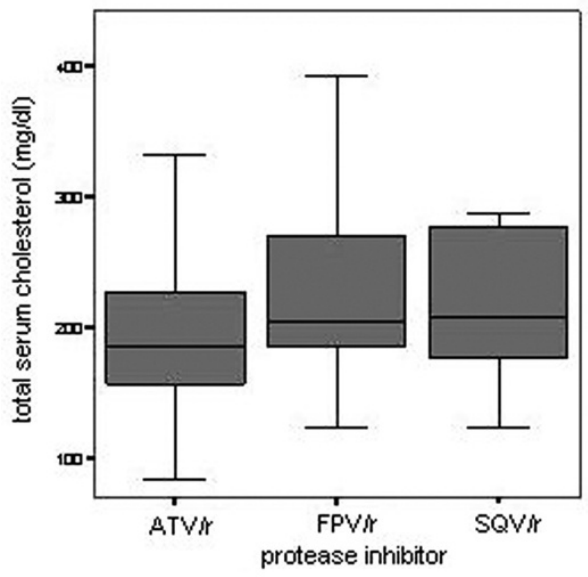

Fig. 1. Change of serum cholesterol levels in the course of the therapy.

In the boxplot, the central line represents the median, the box denotes the inter quartile range, the whiskers encompass the 1,5fold inter quartile range, outliers are not indicated and SQV/r-group the values were $228 \mathrm{mg} / \mathrm{dl}$ and 214 $\mathrm{mg} / \mathrm{dl}$, respectively.

The median serum triglyceride level at baseline in the FPV/r-group was at $136 \mathrm{mg} / \mathrm{dl}$ and thus in the favourable range below $150 \mathrm{mg} / \mathrm{dl}[3,4,55,56]$. In the patients starting therapy with $\mathrm{ATV} / \mathrm{r}$ and $\mathrm{SQV} / \mathrm{r}$ the median baseline values for the triglycerides were 187 $\mathrm{mg} / \mathrm{dl}$ and $205 \mathrm{mg} / \mathrm{dl}$, respectively. After the first 6 months of PI therapy the median value in the ATV/rcollective remained basically unchanged at $187 \mathrm{mg} / \mathrm{dl}$ whereas an increase to $169 \mathrm{mg} / \mathrm{dl}$ in the $\mathrm{FPV} / \mathrm{r}$ group 
and an increase to $218 \mathrm{mg} / \mathrm{dl}$ in the $\mathrm{SQV} / \mathrm{r}$ group were observed. However, neither the inter-group differences nor the changes over time within the different PI groups were statistically significant (Table 2).

Median serum glucose values showed no significant variation between the comparison groups and no relevant changes over the time course of the therapy with the PIs. The majority of the patients in all three groups had normal fasting serum glucose levels below $110 \mathrm{mg} / \mathrm{dl}$ throughout the study period (Table 2).

At baseline the proportion of patients with high cardiovascular risk, i.e., a HeartScore-risk of $>5 \%$, $3,54]$, was highest at $27 \%$ in the group starting therapy with $\mathrm{ATV} / \mathrm{r}$. In the $\mathrm{FPV} / \mathrm{r}$-group and $\mathrm{SQV} / \mathrm{r}$ group the prevalence was $9 \%$ and $12 \%$, respectively. After 6 months of PI therapy the proportion of highrisk patients was slightly lower in the ATV/r-group at $24 \%$. In the other groups a trend towards a rise to $13 \%$ and $18 \%$ could be observed in the patients taking $\mathrm{FPV} / \mathrm{r}$ and SQV/r, respectively (Table 2).

There were no statistically significant differences between the PIs regarding their efficacy in suppressing HIV. Less than half of the patients in all PI-groups had a non-detectable viral load at baseline. After 6 months of therapy the proportion had risen to $>70 \%$. The median CD4-cell count was between 262 and 343 cells/ $\mu \mathrm{l}$ at baseline and rose to values between 292 and 400 cells $/ \mu$ after 6 months of therapy.

\section{Multivariate Linear Regression}

Among the covariates tested only BMI at baseline was identified as confounding the association between PI group (ATV/r vs. SQV/r vs. FPV/r) and cholesterol level at month 6 and therefore was included in the final model. In addition, significant interaction between treatment with $\mathrm{FPV} / \mathrm{r}$ and BMI at baseline was detected (Table 3).

Table 3. Multivariate linear regression model for serum cholesterol levels after 6 months of PI-therapy.

\begin{tabular}{lccc}
\hline Parameter & Coefficient & p-value & $\mathbf{R}^{2 \mathbf{a}}$ \\
\hline intercept & 59.9 & 0.071 & \\
Therapy using ATV/r & reference & & \\
Therapy using SQV/r & 34.5 & 0.007 & \\
Therapy using FPV/r & -83.8 & 0.15 & \\
FPV/r $\times$ BMI at baseline & 5.6 & 0.021 & \\
BMI at baseline & 1.5 & 0.26 & \\
Serum cholesterol at baseline & 0.5 & $<0.001$ & \\
\hline & & & 0.49 \\
\hline
\end{tabular}

a: Coefficient of determination of the regression model

The effect of this interaction can be illustrated by dichotomizing BMI at the median value of 23.5 $\mathrm{kg} / \mathrm{m} 2$ (Table 4). While for patients with higher BMI values the use of FPV/r was associated with the highest cholesterol levels after 6 months, for patients with lower BMI predicted serum cholesterol in the FPV/r
Table 4. Influence of BMI stratum on the effect of FPV/ $r$ on the serum cholesterol level after 6 months of PI therapy.

\begin{tabular}{lcc}
\hline Parameter & Coefficient & p-value \\
\hline $\mathrm{ATV} / \mathrm{r}$ & reference & \\
$\mathrm{SQV} / \mathrm{r}$ & 36.6 & 0.004 \\
$\mathbf{F P V} / \mathrm{r}$ & & \\
$\quad$ for $\mathrm{BMI}>\mathbf{2 3 . 5} \mathrm{kg} / \mathrm{m}^{2}$ & 58.1 & $<0.001$ \\
$\quad$ for $\mathrm{BMI} \leq 23.5 \mathrm{~kg} / \mathrm{m}^{2}$ & 36.6 & 0.023 \\
Serum cholesterol at baseline & 0.5 & $<0.001$ \\
BMI of $>\mathbf{2 3 . 5} \mathrm{kg} / \mathrm{m}^{2}$ at baseline & 15.0 & 0.13 \\
\hline
\end{tabular}

group was identical to those in the SQV/r group (all compared to therapy with ATV/r).

\section{Discussion}

In this cohort study comparing the effect of cART either containing ATV/r, SQV/r, or FPV/r on serum cholesterol levels after 6 months of therapy under real-life conditions we demonstrated the lowest serum cholesterol levels in the ATV/r treated patients. This is even more remarkable considering that at baseline the median serum cholesterol level was highest in the ATV/r group. During the first 6 months of therapy the median serum cholesterol significantly decreased by $18 \mathrm{mg} / \mathrm{dl}$ in the ATV/r-group ( $=0.009)$, whereas in the FPV/r and SQV/r-groups an increase in median cholesterol was observed. Thus, in contrast to baseline the serum cholesterol profile at month 6 was most favourable in the patients taking ATV $/ r$. The observed differences of $>20 \mathrm{mg} / \mathrm{dl}$ in median serum cholesterol between the groups appear clinically relevant, especially in patients at a high cardiovascular risk, even though predefined statistical significance was missed for the bivariate inter-group comparison $(p=0.055)$, likely due to the differences in baseline median cholesterol values between the PI groups. When adjusting for different baseline levels by comparing the median relative changes in serum cholesterol during the first 6 months of therapy the difference between the PI-groups is significant $(p=0.0002)$ and strongly in favour of therapy with ATV/r. Therefore our study confirms the favourable influence of $\mathrm{ATV} / \mathrm{r}$ on serum cholesterol described in current literature [42-45, 52, 57-60].

For SQV/r several trials have indicated a comparatively beneficial influence on serum cholesterol [24, $39,46,47]$, an effect not replicated in our study where treatment with $\mathrm{SQV} / \mathrm{r}$ was associated with a modest increase in serum cholesterol.

In contrast to the Alert-study [52], our findings confirm the rather disadvantageous effect of $\mathrm{FPV} / \mathrm{r}$ on serum cholesterol [27] found in several other studies $[50,51,61]$. However, considering the interaction identified in the multivariate linear regression model, this unfavourable effect of FPV/r on serum cholesterol may not be universal but seems to mainly affect patients with a higher BMI. This suggests that while it might be prudent to avoid therapy with FPV/r in obese patients, FPV/r may be a relatively safe treatment option in patients with normal weight. 
With serum cholesterol being one of the main established cardiovascular risk factors [3-5, 8], calculated cardiovascular risk within the first 6 months of PI therapy parallelled the changes in cholesterol values: in the group taking ATV/r the proportion of patients with high cardiovascular risk decreased, whereas in the patients using FPV/r and SQV/r the proportion with high cardiovascular risk increased.

The HeartSCORE used here for determining the patients' cardiovascular risk has not been validated in HIV-infected populations so far. However, its advantage over other available cardiovascular risk calculators is its validation specifically in European populations. Furthermore, based on parameters readily available through measurements in clinical routine, it describes the risk of a fatal cardiovascular event rather than other, less clearly defined endpoints [2].

It is well known that atherosclerosis is most strongly associated with levels of LDL-cholesterol [4, 26], which were not available for many patients in this study. However, there is a robust correlation between LDL-cholesterol and total serum cholesterol, therefore the latter can well serve as a surrogate variable for determining a patient's cardiovascular risk profile [4].

Another limitation of the study is the relatively small sample size and the unbalanced distribution of patients between the comparison groups, potentially leading to an impairment of statistical significance of some of the analyses. However, the group of patients examined here can be regarded as a representative sample of HIV-infected individuals in Germany based on their demographic characteristics [62]. Furthermore, different univariate and multivariate approaches to analyze the effect of the examined PIs on serum cholesterol yielded consistent results, demonstrating the robustness of the statistical analyses. An immanent limitation of a non-interventional, retrospectively analyzed study is the potential problem of missing data and incomplete data standardization. This was minimized by the use of different data sources including chart documentation of regular clinic visits scheduled every three months and a standardized patient database established at the clinic since 1997. In addition, a main strength of this study is the analysis of data derived from a real-life patient population. In this way clinical reality can be better represented than by the highly selected patient populations used for interventional studies.

In conclusion, in a real-life patient population we confirmed that treatment of HIV infection with a $\mathrm{ATV} / \mathrm{r}$ based regimen had a more favourable impact on serum cholesterol levels and therefore cardiovascular risk compared to $\mathrm{SQV} / \mathrm{r}$ or $\mathrm{FPV} / \mathrm{r}$ based regimens. $\mathrm{FPV} / \mathrm{r}$ was associated with the highest increase in serum cholesterol, specifically in overweight patients, whereas its effects on cholesterol may be comparable to $\mathrm{SQV} / \mathrm{r}$ in patients with a $\mathrm{BMI} \leq 23,5 \mathrm{~kg} / \mathrm{m}^{2}$. In the light of growing interest in personalized medicine [63] and with obesity and cardiovascular disease getting ever more prevalent $[4,64-68]$ this may be an example of how to better tailor cART regimens considering a patient's metabolic and cardiovascular profile.

Based on these results more and larger studies should be undertaken to specifically address the multi- ple interdependencies between effects of cART and patient characteristics affecting cardiovascular risk.

\section{REFERENCES}

1. Assmann G, Schulte H, Cullen P, Seedorf U. Assessing risk of myocardial infarction and stroke: new data from the Prospective Cardiovascular Munster (PROCAM) study. European Journal of Clinical Investigation 2007 Dec;37(12):925-32.

2. Conroy RM, Pyorala K, Fitzgerald AP, et al. Estimation of ten-year risk of fatal cardiovascular disease in Europe: the SCORE project. European Heart Journal 2003 Jun;24(11):987-1003.

3. Graham I, Atar D, Borch-Johnsen K, et al. European guidelines on cardiovascular disease prevention in clinical practice: executive summary. European Heart Journal 2007 Oct;28(19):2375-414.

4. Adult Treatment Panel III. Executive Summary of The Third Report of The National Cholesterol Education Program (NCEP) Expert Panel on Detection, Evaluation, And Treatment of High Blood Cholesterol In Adults (Adult Treatment Panel III). JAMA 2001 May 16;285(19): 2486-97.

5. Lloyd-Jones DM, Wilson PWF, Larson MG, et al. Lifetime Risk of Coronary Heart Disease by Cholesterol Levels at Selected Ages. Archives of Internal Medicine 2003;163(16):1966-72.

6. Bhargava A. A longitudinal analysis of the risk factors for diabetes and coronary heart disease in the Framingham Offspring Study. Popul Health Metr 2003;1(3):1-16.

7. Greenland P, Knoll MD, Stamler J, et al. Major Risk Factors as Antecedents of Fatal and Nonfatal Coronary Heart Disease Events. JAMA Vol. 290: Am Med Assoc, 2003:891-7.

8. Lewington S, Whitlock G, Clarke R, et al. Blood cholesterol and vascular mortality by age, sex, and blood pressure: a meta-analysis of individual data from 61 prospective studies with 55,000 vascular deaths. Lancet $2007 \mathrm{Dec}$ 1;370(9602):1829-39.

9. Niederlaender E. Causes of death in the EU. A report by the EU's statistical office, Eurostat European Communities 2006.

10. Kung HC, Hoyert DL, Xu J, Murphy SL. Deaths: final data for 2005. Natl Vital Stat Rep 2008 Apr 24;56(10):1120.

11. Bundesamt S. Todesursachen - Sterbefälle insgesamt 2007 nach den 10 häufigsten Todesursachen. Last access on August 22, 2008 at

http://www.destatis.de/jetspeed/portal/cms/Sites/ destatis/Internet/DE/Content/Statistiken/Gesundheit/ Todesursachen/Tabellen/Content75/SterbefaelleInsge samt,templateId = renderPrint.psml

12. Bundesamt S. Todesursachen in Deutschland - Gestorbene in Deutschland an ausgewählten Todesursachen 2006. Statistisches Bundesamt, 2006.

13. Detels R, Munoz A, McFarlane G, et al. Effectiveness of potent antiretroviral therapy on time to AIDS and death in men with known HIV infection duration. Multicenter AIDS Cohort Study Investigators. JAMA 1998 Nov 4;280(17):1497-503.

14. Bhaskaran K, Hamouda O, Sannes M, et al. Changes in the risk of death after HIV seroconversion compared with mortality in the general population. JAMA $2008 \mathrm{Jul}$ 2;300(1):51-9.

15. Lewden C, May T, Rosenthal E, et al. Causes de décès en France en 2005 des adultes infectées par le VIH et évolution par rapport à 2000. Bulletin épidémiologique hebdomadaire 200628 November 2006(48):37982. 
16. Palella FJ, Jr., Baker RK, Moorman AC, et al. Mortality in the highly active antiretroviral therapy era: changing causes of death and disease in the HIV outpatient study. J Acquir Immune Defic Syndr 2006 Sep;43(1):27-34.

17. Crum NF, Riffenburgh RH, Wegner S, et al. Comparisons of causes of death and mortality rates among HIVinfected persons: analysis of the pre-, early, and late HAART (highly active antiretroviral therapy) eras. J Acquir Immune Defic Syndr 2006 Feb 1;41(2):194-200.

18. El-Sadr WM, Lundgren JD, Neaton JD, et al. CD4+ Count-guided interruption of antiretroviral treatment. New England Journal of Medicine 2006;355(22):2283-96.

19. Phillips AN, Carr A, Neuhaus J, et al. Interruption of antiretroviral therapy and risk of cardiovascular disease in persons with HIV-1 infection: exploratory analyses from the SMART trial. Antivir Ther 2008;13(2):177-87.

20. Grunfeld C, Pang M, Doerrler W, Shigenaga JK, Jensen P, Feingold KR. Lipids, lipoproteins, triglyceride clearance, and cytokines in human immunodeficiency virus infection and the acquired immunodeficiency syndrome. J Clin Endocrinol Metab 1992 May;74(5):1045-52.

21. Neumann T, Miller M, Esser S, Gerken G, Erbel R. Arteriosklerose bei HIV-positiven Patienten. Zeitschrift für Kardiologie 2002;91(11):879-88.

22. Friis-Moller N, Weber R, Reiss P, et al. Cardiovascular disease risk factors in HIV patients--association with antiretroviral therapy. Results from the DAD study. AIDS 2003 May 23;17(8):1179-93.

23. Friis-Moller N, Sabin CA, Weber R, et al. Combination antiretroviral therapy and the risk of myocardial infarction. N Engl J Med 2003 Nov 20;349(21):1993-2003.

24. Fellay J, Boubaker K, Ledergerber B, et al. Prevalence of adverse events associated with potent antiretroviral treatment: Swiss HIV Cohort Study. Lancet 2001 Oct 20;358 (9290):1322-7.

25. Friis-Moller N, Reiss P, Sabin CA, et al. Class of antiretroviral drugs and the risk of myocardial infarction. $\mathrm{N}$ Engl J Med 2007 Apr 26;356(17):1723-35.

26. Baigent C, Keech A, Kearney PM, et al. Efficacy and safety of cholesterol-lowering treatment: prospective metaanalysis of data from 90,056 participants in 14 randomised trials of statins. Lancet 2005 Oct 8;366(9493): 1267-78.

27. Lundgren JD, Battegay M, Mallon P, et al. European AIDS Clinical Society (EACS) guidelines: Prevention and management of non-infectious co-morbidities in HIV, version 5, Nov 2009. Last access on May 3, 2010 at http:/ / wwweuropeanaidsclinicalsocietyorg/guidelinespdf/2_Non_Infectious_Co_Morbidities_in_HIVpdf.

28. Clumeck N, Dedes N, Pozniak A, Raffi F, the EACS Executive Committee. European AIDS Clinical Society (EACS) guidelines for the clinical management and treatment of HIV-infected adults, version 5, Nov 2009. last access on Sept. 6, 2010 at http://www.europeanaidsclini calsociety.org/Guidelines/ index.htm

29. Centers for Disease Control and Prevention. About BMI for Adults. Healthy Weight 2009. Last access on January 27,2010 at http://www.cdc.gov/healthyweight/assessing/ bmi/adult_bmi/index.html

30. Thompson MA, Aberg JA, Cahn P, et al. Antiretroviral treatment of adult HIV infection: 2010 recommendations of the International AIDS Society-USA panel. JAMA 2010 Jul 21;304(3):321-33.

31. Deutsche AIDS Gesellschaft, Österreichische AIDS Gesellschaft. Deutsch-Österreichische Leitlinien zur antiretroviralen Therapie der HIV-1-Infektion. Last access on September 9, 2010 at http://www.daignet.de/site-content/hiv-therapie/leitlin ien-1/resolveuid/4e09c351567524bfd215f4d46a9b6f5a.

32. Purnell JQ, Zambon A, Knopp RH, et al. Effect of ritonavir on lipids and post-heparin lipase activities in normal subjects. AIDS 2000 Jan 7;14(1):51-7.
33. Sullivan AK, Nelson MR. Marked hyperlipidaemia on ritonavir therapy. AIDS 1997 Jun;11(7):938-9.

34. Martinez E, Domingo P, Galindo MJ, et al. Risk of metabolic abnormalities in patients infected with HIV receiving antiretroviral therapy that contains lopinavir-ritonavir. Clin Infect Dis 2004 Apr 1;38(7):1017-23.

35. Walmsley S, Bernstein B, King M, et al. Lopinavir-ritonavir versus nelfinavir for the initial treatment of HIV infection. N Engl J Med 2002 Jun 27;346(26):2039-46.

36. Dube MP, Stein JH, Aberg JA, et al. Guidelines for the evaluation and management of dyslipidemia in human immunodeficiency virus (HIV)-infected adults receiving antiretroviral therapy: recommendations of the HIV Medical Association of the Infectious Disease Society of America and the Adult AIDS Clinical Trials Group. Clin Infect Dis 2003 Sep 1;37(5):613-27.

37. Tsiodras S, Mantzoros C, Hammer S, Samore M. Effects of protease inhibitors on hyperglycemia, hyperlipidemia, and lipodystrophy: a 5-year cohort study. Arch Intern Med 2000 Jul 10;160(13):2050-6.

38. Periard D, Telenti A, Sudre P, et al. Atherogenic dyslipidemia in HIV-infected individuals treated with protease inhibitors. The Swiss HIV Cohort Study. Circulation 1999 Aug 17;100(7):700-5.

39. Fontas E, van Leth F, Sabin CA, et al. Lipid profiles in HIV-infected patients receiving combination antiretroviral therapy: are different antiretroviral drugs associated with different lipid profiles? J Infect Dis 2004 Mar 15;189(6):1056-74.

40. Lee GA, Seneviratne T, Noor MA, et al. The metabolic effects of lopinavir/ritonavir in HIV-negative men. AIDS 2004 Mar 5;18(4):641-9.

41. Lafeuillade A, Hittinger G, Philip G, Lambry V, Jolly P, Poggi C. Metabolic evaluation of HIV-infected patients receiving a regimen containing lopinavir/ritonavir (Kaletra). HIV Clinical Trials 2004 Nov-Dec;5(6):392-8.

42. Gatell J, Salmon-Ceron D, Lazzarin A, et al. Efficacy and safety of atazanavir-based highly active antiretroviral therapy in patients with virologic suppression switched from a stable, boosted or unboosted protease inhibitor treatment regimen: the SWAN Study (AI424-097) 48-week results. Clin Infect Dis 2007 Jun 1;44(11):1484-92.

43. Molina JM, Andrade-Villanueva J, Echevarria J, et al. Once-daily atazanavir/ritonavir versus twice-daily lopinavir/ritonavir, each in combination with tenofovir and emtricitabine, for management of antiretroviral-naive HIV-1-infected patients: 48 week efficacy and safety results of the CASTLE study. Lancet 2008 Aug 23;372(9639):646-55.

44. Mobius U, Lubach-Ruitman M, Castro-Frenzel B, et al. Switching to atazanavir improves metabolic disorders in antiretroviral-experienced patients with severe hyperlipidemia. J Acquir Immune Defic Syndr 2005 Jun 1;39(2):174-80.

45. Cahn PE, Gatell JM, Squires K, et al. Atazanavir--a oncedaily HIV protease inhibitor that does not cause dyslipidemia in newly treated patients: results from two randomized clinical trials. J Int Assoc Physicians AIDS Care (Chic Ill) 2004 Jul-Sep;3(3):92-8.

46. Segerer S, Bogner JR, Walli R, Loch O, Goebel FD. Hyperlipidemia under treatment with proteinase inhibitors. Infection 1999 Mar-Apr;27(2):77-81.

47. Dragsted UB, Gerstoft J, Pedersen C, et al. Randomized trial to evaluate indinavir/ritonavir versus saquinavir/ritonavir in human immunodeficiency virus type 1 -infected patients: the MaxCmin1 Trial. J Infect Dis 2003 Sep 1;188(5):635-42.

48. Dragsted UB, Gerstoft J, Youle M, et al. A randomized trial to evaluate lopinavir/ritonavir versus saquinavir/ritonavir in HIV-1-infected patients: the MaxCmin2 trial. Antivir Ther 2005;10(6):735-43. 
49. Manfredi R, Chiodo F. Disorders of lipid metabolism in patients with HIV disease treated with antiretroviral agents: frequency, relationship with administered drugs, and role of hypolipidaemic therapy with bezafibrate. J Infect 2001 Apr;42(3):181-8.

50. Eron J, Jr., Yeni P, Gathe J, Jr., et al. The KLEAN study of fosamprenavir-ritonavir versus lopinavir-ritonavir, each in combination with abacavir-lamivudine, for initial treatment of HIV infection over 48 weeks: a randomised non-inferiority trial. Lancet 2006 Aug 5;368(9534):476-82.

51. Gathe JC, Jr., Ive P, Wood R, et al. SOLO: 48-week efficacy and safety comparison of once-daily fosamprenavir / ritonavir versus twice-daily nelfinavir in naive HIV-1-infected patients. AIDS 2004 Jul 23;18(11):1529-37.

52. Smith KY, Weinberg WG, Dejesus E, et al. Fosamprenavir or atazanavir once daily boosted with ritonavir 100 $\mathrm{mg}$, plus tenofovir/emtricitabine, for the initial treatment of HIV infection: 48-week results of ALERT. AIDS Res Ther 2008;5:5.

53. European Society of Cardiology. HeartScore Programme. 2009. Last access on February 27, 2010 at http://www.heartscore.org/Pages/welcome.aspx

54. De Backer G, Ambrosioni E, Borch-Johnsen K, et al. European guidelines on cardiovascular disease prevention in clinical practice. Third Joint Task Force of European and Other Societies on Cardiovascular Disease Prevention in Clinical Practice. European Heart Journal 2003 Sep;24 (17):1601-10.

55. Grundy SM, Brewer HB, Jr., Cleeman JI, Smith SC, Jr., Lenfant C. Definition of metabolic syndrome: Report of the National Heart, Lung, and Blood Institute/American Heart Association conference on scientific issues related to definition. Circulation 2004 Jan 27;109(3):433-8.

56. Alberti KG, Zimmet P, Shaw J. The metabolic syndrome-a new worldwide definition. Lancet 2005 Sep 2430;366(9491):1059-62.

57. Johnson M, Grinsztejn B, Rodriguez C, et al. Atazanavir plus ritonavir or saquinavir, and lopinavir/ritonavir in patients experiencing multiple virological failures. AIDS 2005 Apr 29;19(7):685-94.

58. Johnson M, Grinsztejn B, Rodriguez C, et al. 96-week comparison of once-daily atazanavir/ritonavir and twicedaily lopinavir/ritonavir in patients with multiple virologic failures. AIDS 2006 Mar 21;20(5):711-8.

59. Mallolas J, Podzamczer D, Milinkovic A, et al. Efficacy and safety of switching from boosted lopinavir to boosted atazanavir in patients with virological suppression receiving a LPV/r-containing HAART: the ATAZIP study. J Acquir Immune Defic Syndr 2009 May 1;51(1):29-36.

60. Wood R, Phanuphak P, Cahn P, et al. Long-term efficacy and safety of atazanavir with stavudine and lamivudine in patients previously treated with nelfinavir or atazanavir. J Acquir Immune Defic Syndr 2004 Jun 1;36(2):684-92.

61. Rodriguez-French A, Boghossian J, Gray GE, et al. The NEAT study: a 48-week open-label study to compare the antiviral efficacy and safety of GW433908 versus nelfinavir in antiretroviral therapy-naive HIV-1-infected patients. J Acquir Immune Defic Syndr 2004 Jan 1;35(1):2232.
62. Robert Koch-Institut. HIV/AIDS in Deutschland -Eckdaten, Epidemiologische Kurzinformation des Robert Koch-Instituts, Stand: Ende 2008. Last access on June 30, 2009 at

http://www.rki.de/cln_100/nn_195960/DE/Content/ InfAZ/H/HIVAIDS/Epidemiologie/Daten__und_Ber ichte $/$ EckdatenDeutschland, templateId $=$ raw, property $=p$ ublicationFile.pdf/EckdatenDeutschland.pdf

63. Institute for Pharmacogenomics and Individualized Therapy. Homepage of the Institute for Pharmacogenomics and Individualized Therapy. 2007. Last access on December 10, 2009 at http://www.ipit.unc.edu/

64. Hauner H, Buchholz G, Hamann B, Koletzko B. Prävention und Therapie der Adipositas - Evidenzbasierte Leitlinie Version 2007. 2007.

65. Gesundheitsberichtserstattung des Bundes. Cholesterinmesswerte im Bundes-Gesundheitssurvey 1998 in Deutschland. Last access on May 20, 2009 at http://www.gbe-bund.de/gbe10/abrechnung.prc_abr_ test_logon?p_uid=gastg\&p_aid=\&p_knoten $=$ FID\&p_sp rache=D\&p_suchstring=4228::Cholesterin

66. Gesundheitsberichtserstattung des Bundes. Body Mass Index (BMI) der erwachsenen Bevölkerung. 1998. Last access on August 30, 2009 at

http://www.gbe-bund.de/gbe10/abrechnung.prc_ abr_test_logon?p_uid=gastg\&p_aid=\&p_knoten=FID\& p_sprache $=$ D\&p_suchstring $=8397::$ Body-Mass-Index

67. Gesundheitsberichtserstattung des Bundes. Bluthochdruck - Gesundheit in Deutschland, 2006. Last access on August 30, 2009 at http://www.gbe-bund.de/gbe10/abrechnung.prc_ abr_test_logon?p_uid=gastg\&p_aid=\&p_knoten=FID\& p_sprache=D\&p_suchstring $=10700::$ Hypertonie

68. Diabetes Deutschland. Diabetes: Themen und Fakten Die aktuelle Situation. Diabetes: Themen und Fakten 2007. Last access on August 30, 2009 at http://www.diabetes-deutschland.de/aktuellesituat ion.html

Received: November 1, 2010 / Accepted: November 1, 2010

Address for correspondence:

Dr. Miriam Gyalrong-Steur

Infektionsambulanz und Tagesklinik

Medizinische Poliklinik der

Ludwig-Maximilians-Universität - Innenstadt

Pettenkoferstraße $8 \mathrm{a}$

80336 München

Germany

Phone: $++49-151-56168156$

Fax: $\quad++49-89-51603550$

Email: m_c_gyalrong@hotmail.de 